\title{
The Effects of Foliar Vermicompost Applications on Yield and Some Yield Components in Triticale Varieties
}

\author{
Kamil Kara ${ }^{1, a, *}$, Taşkın Erol ${ }^{2, b}$, Aykut Şener ${ }^{3, c}$ \\ ${ }^{1}$ Organic Agriculture Programme, Delice Vocational School, Kırlkkale University, 71700 Delice, Kirlkkale, Turkey \\ ${ }^{2}$ Organic Agriculture Programme, Kırıkkale Vocational School, Kırıkkale University, 71450, Yahşihan/Kırıkkale, Turkey \\ ${ }^{3}$ Department of Field Crops Faculty of Agriculture, Isparta University of Applied Sciences, 32200 Isparta, Turkey \\ *Corresponding author
}

A R T I C L I N F O A B S T R A T

Research Article

Vermicompost fertilizers have started to attract attention in agriculture last years. Various liquid vermicompost fertilizers are produced and used in agriculture and some of them known as vermiliquer, vermi leachate, vermi tea or vermicast with little differences. This study is aimed to determine the effects of foliar application of liquid vermicompost fertilizer on yield and some yield

Received : 28/03/2021

Accepted : 05/05/2021 components on some Turkey triticale varieties under Central Anatolian conditions in Kirıkkale province during the growing period 2014-15 and 2015-16. Six different (control, 75, 150, 250, 350 and $450 \mathrm{cc} \mathrm{da}^{-1}$ ) liquid vermicompost fertilizer doses were applied by the foliar spraying method at the beginning and end of March in both years to the five Turkey triticale varieties (Alperbey, Mikham 2002, Tatlıcak 97, Karma 2000 and Ümranhanım). According to the results, plant height,

Keywords:

Triticale grain number and grain yield in spike, grain yield per decare, harvest index and protein content results were found to be significant in fertilizer $\times$ variety $\times$ year interaction. There is also a statistically significant difference between thousand-grain weight and the variety $\mathrm{x}$ fertilizer doses Foliar

Liquid Vermicompost Fertilizer Yield interaction, and between varieties and fertilizer doses in terms of spike length. The positive effects of liquid vermicompost fertilizer doses, except $450 \mathrm{cc} \mathrm{da}{ }^{-1}$, were determined in varieties. It was Yield Components observed that a satisfactory yield can be obtained from $250 \mathrm{cc} \mathrm{da}^{-1}$ in the absence of nitrogen fertilizers as the top fertilizer. It could be deduced that 250-350 $\mathrm{cc} \mathrm{da}^{-1}$ doses of vermicompost fertilizer can be applied in triticale based on varying ecological conditions and varieties in Central Anatolian ecological conditions.

\section{Introduction}

Triticale varieties can be both more productive and stable than wheat in less deep and barren soils and under harsh winter conditions with their high adaptation capabilities (Martin and Maurer, 1974; Akgün et al., 2007). As triticale has low ecological demands, is easy to maintain and can be cultivated under winter conditions and an alternative in the economic evaluation of fields where rye, wheat and barley are cultivated and the yield is low (Atak, 2004). Wheat and barley cultivation will shift to soils that are more suitable for ecological demands when triticale is cultivated in marginal fields. Therefore, the yield per unit area of wheat or barley may increase (Akgün et al., 2007). Studies highlight that triticale is similar or superior to other cereal species in terms of protein content, amino acid distribution, feed yield, dry matter and fibre content, and feed digestibility (Fernandez-Figares 2000; Atak, 2004). It is also said that due to its high mineral content (phosphorus, manganese, iron, copper and calcium), grains can be used directly in animal feed or added to rations (especially pigs and poultry) (Çiftçi et al., 2003). Flour yield is low in triticale varieties due to wrinkled grain and low hectolitre weight. Just as stated, triticale flour is mixed with wheat and rye flour in certain proportions (50-70\%) and used in human nutrition as bread, cake and crackers (Navarro-Contreras et al., 2014; McGoverin et al., 2011). Today, bread can be made entirely from triticale flour by using newly improved varieties and it can be suitable for human nutrition in point of agricultural features. There is 
an increasing trend in triticale cultivation and production due to the development of varieties suitable for market demands in our country recently (Atak, 2004; Akgün et al., 2007). Based on the data of 2019, 215.000 tons of crops were grown from approximately 64.000 ha fields in Turkey, and the seed yield per unit area was approximately $336 \mathrm{~kg} \mathrm{da}^{-1}$ (FAO, 2019). To increase the production of triticale, it is necessary to develop new varieties and improve the cultivation techniques depending on the changing ecological conditions. In this respect, one of the most important factors in yield increases is the determination of the most suitable plant nutrition and fertilization methods to the genotypes that suits the climate and soil conditions of the region (Sönmez et al., 2008). Excessive use of synthetic fertilizers and pesticides in traditional agriculture has threatened the environment and human health for the last 50-60 years. Due to the failure to apply appropriate fertilizer types in the recommended doses and periods in plant nutrition, significant economic losses may occur and environmental problems arise such as barrenness and salinity in soils, cation and anion imbalance in soil solution, heavy metal pollution, reduction in microbial activities, eutrophication and $\mathrm{NO}_{3}$ accumulation in water, emission of $\mathrm{N}, \mathrm{S}$ and greenhouse gases to the atmosphere. Studies have reported that nitrogen use in nitrogen fertilizers is approximately $50 \%$ (Okur et al., 2007; Sönmez et al., 2008; Karaşahin, 2014). Organic fertilization can be an alternative to prevent these losses and increase crop production without harming natural resources (Süzer, 2020). While organic fertilizers increase cell division, plant growth rate and photosynthetic activity in plants, they also increase the resistance of plants against pests and pathogens. By improving the physical, chemical and biological properties of the soils, it ensures that the vitality and productivity of the soil are sustainable (Okur et al., 2007; Anonymous 2020; Süzer, 2020). The range of materials defined as organic fertilizers like barn manure, green manure, household and city wastes, composts, slaughterhouse waste products, straw, sawdust, peat, seaweed, natural rocks and vermicomposts has expanded in recent years (Süzer, 2020). Vermicompost is an organic fertilizer obtained by converting organic products such as vegetables or food waste into humus-like substances utilizing special worms. Body fluids (coelom fluids) involved in worms pass into their faeces through both contact and digestive systems (Teke et al., 2019). In addition to providing resistance against diseases in plants, vermicomposts can be used as biological fertilizers thanks to the Rhizobial bacteria, mycorrhiza fungi, enzymes, phytohormones, humic/fulvic acids, amino acids and high rate of plant nutrients (Coşkan and Şenyiğit, 2018). In studies, it was confirmed that vermicomposts provide healthy and rapid growth in plants (Arancon et al., 2012; Coşkan and Yilmaz, 2015), and have positive and significant effects on both unit area yield and product quality in many cultivated plants (Quiroz et al., 2014; Coşkan and Şenyiğit, 2018; Arancon et al., 2019; Teke et al., 2019).

In this study, it was aimed to reveal the foliar applicability and the effects of different doses of vermicomposts which have become widespread in agricultural production in recent years, on some yield characteristics of triticale varieties.

\section{Material and Method}

\section{Material}

This research was conducted for two years in the trial fields of Kirıkkale University, Delice Vocational School in the vegetation period of 2015-2016. Alperbey, Mikham 2002 and Tatlicak 97 triticale varieties brought from Bahri Dağdaş International Agricultural Research Institute, Konya, Turkey, Karma 2000 variety from Anatolian Agricultural Research Institute, Eskişehir, Turkey and Ümranhanım variety from the private sector seed company. In the study, $100 \%$ liquid vermicompost product (Nanonat brand fertilizer provided by Nanotim Company) which can be applied by foliar spray was used and the ingredients of this fertilizer are; $200 \mathrm{~g} / \mathrm{l}$ organic matter, 100 $\mathrm{g} / \mathrm{l}$ total humic-fulvic acids, total $\mathrm{P}$ is $1.1 \mathrm{~g} / \mathrm{l}$, total $\mathrm{N}$ is 2.1 $\mathrm{g} / \mathrm{l}$, total $\mathrm{K}$ is $2.0 \mathrm{~g} / \mathrm{l}$ and $\mathrm{pH}$ is 7.4. (www.nanotim.com, 2013).

In the trial, 6 different (control, 75, 150, 250, 350 and $450 \mathrm{cc} \mathrm{da}^{-1}$ ) doses of liquid vermicompost fertilizer were applied.

\section{Climate and Soil Characteristics of the Trial Field}

The trial was conducted in Kirikkale (33 31 E, $3950 \mathrm{~N}$ ) that is located in the continental climate zone in the Central Anatolia region. Winters are quite cool and rainy, and summers are hot and dry in the region.

The total precipitation during the first-year vegetation period (Oct. 2014-Jul. 2015) was $395.6 \mathrm{~mm}$ and was higher than the long-term $(386.4 \mathrm{~mm})$ and the second-year vegetation period $(337.4 \mathrm{~mm})$. As seen in Table 1, the precipitation in the firs-year vegetation period was observed $58.2 \mathrm{~mm}$ higher than the second-year vegetation period and $9.2 \mathrm{~mm}$ than the second-year vegetation period. Based on the monthly vegetation period temperature averages in both years, it is seen that the second year was warmer than the first-year values, except May. Similarly, monthly temperature values of the second year were higher than the long-term observations.

Soil analysis was done by the TARVAK Soil Analysis Laboratory, Kirıkkale, Turkey. According to the soil analysis results, trial fields are clayey and loamy, almost neutral alkali $(\mathrm{pH}=7.73)$, salt-free, slightly calcareous, poor in organic matter $(1.0 \%)$, and enough in terms of absorbable phosphorus and potassium (573 mg. $\mathrm{kg}^{-1}$ and $95.7 \mathrm{~kg} \mathrm{da}^{-1}$, respectively).

\section{Method}

This research was carried out to determine the effects of different doses of foliar vermicompost fertilizer on yield and some yield characteristics in triticale, and it was established in 3 replications based on the split-plot trial design in random blocks. The varieties were arranged in the main plots and the vermicompost doses were arranged in the subplots. Wheat trial techniques were applied, and the parcels set to be $6 \mathrm{~m}^{2}$, with $1.2 \mathrm{~m}$ in width and $5 \mathrm{~m}$ in length. Each parcel had 6 rows with $20 \mathrm{~cm}$ row spacing. There were $1 \mathrm{~m}$ gaps between the main parcels and blocks and $0.5 \mathrm{~m}$ gaps between the sub-parcels. Sowing was done manually in mid-October in both years, with 550 seeds per square meter. Before planting, Diammonium Phosphate (DAP) fertilizer applied to all plots with $15 \mathrm{~kg} \mathrm{da}^{-1}$. No other fertilization and herbicide applicated except DAP. 
The fertilizer doses were adjusted to $75,150,250,350$ and $450 \mathrm{cc} \cdot \mathrm{da}^{-1}$ of liquid vermicompost in each parcel, and applications were done using a back sprayer for $401 . \mathrm{da}^{-1}$ of water. Only water was pulverized to the control plots. Foliar vermicompost application was repeated in two times with the first week and last week of March in both years. When the plants reached harvest maturity, one row from the edges of each parcel and $50 \mathrm{~cm}$ from each head was not harvested. 10 plants were randomly tagged for morphological observations from the mid-plot. The harvest was done with a sickle in the second week of July. The plants were allowed to dry in bunches for 2-3 days. After the measurements, blending was done with the parcel threshing machine. Under the methods stated by Genç et al. (1988), plant height, spike length, grain number and grain yield in spike, thousand-grain weight, grain yield per decare, harvest index and protein content were determined in the trial.

\section{Data Evaluation}

In the study, variance analysis was performed by using the Tarist Statistical Package program according to the trial design of the split plots, and the significance levels of the differences between the averages were determined based on the Duncan test (5\%).

Table 1. Means of temperature, relative humidity (RH\%) and precipitation at the site of experimentation for 2014,2015 and 2016. (Source: Kırıkkale Meteorology Directorate, Kırıkkale, Turkey)

\begin{tabular}{l|cccccccccccc}
\hline \multirow{2}{*}{ Month } & \multicolumn{4}{|c}{ Precipitation $(\mathrm{mm})$} & \multicolumn{4}{c}{ Temperature $\left({ }^{\circ} \mathrm{C}\right)$} & \multicolumn{4}{c}{ Humidity $(\mathrm{RH} \%)$} \\
\cline { 2 - 12 } & 2014 & 2015 & 2016 & LT & 2014 & 2015 & 2016 & LT & 2014 & 2015 & 2016 & LT \\
\hline Jan & 17.4 & 19.0 & 68.3 & 42.9 & 2.9 & -0.1 & 0.5 & 0.2 & 79.2 & 85.2 & 75.2 & 78.4 \\
Feb & 20.9 & 34.6 & 15.5 & 30.2 & 6.0 & 3.8 & 7.4 & 2.2 & 58.3 & 73.2 & 70.4 & 72.6 \\
Mar & 38.7 & 68.6 & 56.4 & 35.3 & 9.0 & 7.5 & 8.5 & 6.7 & 59.8 & 72 & 63.5 & 64.9 \\
Apr & 6.4 & 15.7 & 5.4 & 45.4 & 14.8 & 9.8 & 14.6 & 12.0 & 48.8 & 58.8 & 51.1 & 61.2 \\
May & 66.0 & 58.7 & 125.9 & 50.3 & 17.1 & 17.4 & 16.0 & 16.5 & 62.0 & 57.4 & 69.9 & 59.3 \\
Jun & 39.4 & 109.1 & 13.0 & 38.1 & 20.9 & 19.7 & 22.2 & 20.8 & 53.7 & 67.9 & 56.9 & 53.9 \\
Jul & 3.7 & 0.0 & 0.5 & 11.7 & 26.6 & 24.3 & 25.1 & 24.2 & 37.7 & 45.7 & 44 & 47.7 \\
Aug & 11.1 & 6.9 & 21.1 & 11.6 & 26.6 & 25.6 & 26.1 & 23.9 & 39.6 & 45.1 & 43.5 & 47.8 \\
Sep & 31.7 & 8.3 & 15.4 & 14.6 & 20.6 & 23.5 & 19.4 & 19.5 & 50.4 & 41.3 & 51.6 & 51.5 \\
Oct & 31.1 & 41.7 & 0.9 & 31.3 & 14.1 & 15.2 & 14.2 & 13.6 & 65.4 & 64 & 50.8 & 62.1 \\
Nov & 45.1 & 5.0 & 29.5 & 32.2 & 6.8 & 8.3 & 5.8 & 6.7 & 74.6 & 59.5 & 60.1 & 71.6 \\
Dec & 13.7 & 5.7 & 33.6 & 42.8 & 5.7 & 0.0 & -0.2 & 2.0 & 84.9 & 79.5 & 78.3 & 78.2 \\
Total & 325.2 & 373.3 & 385.5 & 386.4 & & & & & & & \\
\hline
\end{tabular}

LT: Long Term (46 yr)

\section{Results and Discussion}

\section{Plant Height}

The reaction of the varieties to the fertilizer doses was different to the plant height. As seen in Table 2, the lowest average plant height was obtained in control plots as 95.6 and $91.7 \mathrm{~cm}$, respectively, in both years. Increasing doses of vermicompost caused an increase in plant height up to 350 $\mathrm{cc} \mathrm{da}^{-1}$ in overall averages. Although there was a slight decrease in plant height in all varieties with $450 \mathrm{cc} \mathrm{da}^{-1}$ dose $(99.7 \mathrm{~cm})$, it was higher than the control plots $(93.7 \mathrm{~cm})$.

Depends on the varieties, each variety was affected differently from vermicompost doses and the degree of the effect varied between years. The adverse effect of increasing doses in the first year was higher than in the second year. It can be said that these differences are related to the effects of increasing vermicompost doses due to the different development characteristics of triticale varieties. Some varieties have stronger growth characteristics than others, and the negative effects of high-dose vermicompost are thought to be less affected. Although plant growth is the most affected factor by genotype, environmental conditions such as light, temperature and humidity can also be effective. Top fertilization was not applied in the study. The presence of some phytohormones and organic acids in trace amounts with organic fertilizer applications accelerate plant growth, especially in malnourished plants. Thus, as stated by Arancon et al. (2012), both solid and liquid vermicomposts contains Auxin, Cytokinin and
Gibberellins group hormones and some humic-fulvic acids. The use of these fertilizers in plant growth gives a nonnutritional response to these substances, and they are effective even at low concentrations. The researchers concluded that high doses should be avoided in vermicompost applications, and long-term applications at low doses would yield better results. Similarly, Coşkan and Y1lmaz (2015) reported that liquid vermicompost applications had a positive effect on plant growth contrary to the high dose applications. Besides, it is known that even very low doses of some elements have a great effect on plant growth due to ecological conditions (Kacar and Katkat, 2018). Between the years, first-year means were, either in terms of varieties or vermicompost doses, higher than the second-year values. The first year growing period precipitation values $(395.6 \mathrm{~mm})$ is higher than the second year's values $(337.4 \mathrm{~mm})$, and this difference $(58.2 \mathrm{~mm})$ may have been caused to be the first year's plant heights averages are higher than the second year's averages. It was reported that the most important changes in nutrient content in plant organs are $5 \%$ of vermicompost in $\mathrm{K}$ and Ca elements and $20 \%$ of vermicompost in $\mathrm{Mg}, \mathrm{Na}, \mathrm{Fe}, \mathrm{Mn}$, $\mathrm{Zn}$ and $\mathrm{Cu}$ elements compared to control plants in the application of vermicompost and bio-coal in wheat (Sönmez and Çı̆̆, 2019 ). In the case of foliar application of plant nutrients, vegetative and environmental factors are extremely important during the absorption of these 
substances by the leaves. In such applications, nutrient intake may vary depending on the plant species, environmental factors and application methods. The water in the solution evaporates rapidly, and only salts remain on the leaf surface on hot and sunny days, so nutrient intake is limited. The number of leaves and stomata, the thickness of the cutin layer varies depends on the species, and the nutrient intake efficiency from the leaf may vary (Kacar and Katkat, 2018). Similar to the results we obtained, it was stated that the plant height in cucumber (Rostami et al., 2014; Ekinci et al., 2014), corn (Tankuş, 2019) and chickpea (Uçar et al., 2020) increased due to the increase in both solid and liquid vermicompost doses.

\section{Spike Length}

The differences between years, varieties and vermicompost doses and year $\mathrm{x}$ variety interaction were found to be statistically significant in spike length. Although the spike length in the first year varied between 9.11-9.83 cm, it was determined that the differences between the varieties were statistically insignificant. In the second year, spike lengths increased significantly compared to the first year, and significant differences were found in varieties.

This situation may be associated with the precipitation in April, May and June in 2015 and 2016. As known, high spring precipitation promotes vegetative development in cereals. Correspondingly, higher April and June precipitations in the first year made plant height longer than the second year. Water amount in May (125.9 mm) was excessive in the second year. This may be a reason for airlessness at the root area and a downgrade in development. Under stress conditions, most of the plants try to create generative organs. So, excessive May precipitation in the second year $(125.9 \mathrm{~mm})$ may have affected the spike development positively and resulted in the higher spike length values in the second year. Alperbey variety had the highest spike length both in the second year $(10.87 \mathrm{~cm})$ and in the annual average $(10.17 \mathrm{~cm})$ (Table 3$)$. Averagely, the shortest spike length values obtained in the control plots (overall avg. $9.34 \mathrm{~cm}$ ), and the spike length increased depending on the increasing vermicompost doses. The highest average determined with $9.97 \mathrm{~cm}$ in 450 cc da $\mathrm{da}^{-1}$ application (Table 3 ). The effect of vermicompost doses increased the spike length similar to the plant height.

Table 2. Plant height averages of triticale treated with different doses of foliar vermicompost

\begin{tabular}{|c|c|c|c|c|c|c|c|c|}
\hline \multirow{2}{*}{ Year } & \multirow{2}{*}{ Variety } & \multicolumn{6}{|c|}{ Doses for Vermicompost $\left(\mathrm{cc} \mathrm{da}^{-1}\right)$} & \multirow{2}{*}{ Avg. } \\
\hline & & Control & 75 & 150 & 250 & 350 & 450 & \\
\hline \multirow{5}{*}{ First Year } & Alperbey & $96.8^{\mathrm{cd}}$ & $94.9^{\mathrm{d}}$ & $94.6^{\mathrm{d}}$ & $100.1^{\mathrm{bc}}$ & $105.8^{\mathrm{a}}$ & $101.1^{\mathrm{b}}$ & 98.9 \\
\hline & Tatlicak97 & $97.0^{\mathrm{c}}$ & $102.1^{\mathrm{b}}$ & $102.9^{\mathrm{b}}$ & $104.5^{\mathrm{b}}$ & $110.2^{\mathrm{a}}$ & $105.3^{\mathrm{b}}$ & 103.7 \\
\hline & Karma2000 & $87.4^{\mathrm{e}}$ & $94.8^{\mathrm{cd}}$ & $97.8^{\mathrm{c}}$ & $103.0^{\mathrm{b}}$ & $108.6^{\mathrm{a}}$ & $93.8^{\mathrm{d}}$ & 97.6 \\
\hline & Ümranhanım & $100.4^{\mathrm{b}}$ & $104.6^{\mathrm{a}}$ & $102.2^{\mathrm{ab}}$ & $101.5^{\mathrm{ab}}$ & $101.4^{\mathrm{ab}}$ & $99.5^{\mathrm{b}}$ & 101.6 \\
\hline & Mikham 2002 & $96.4^{\mathrm{d}}$ & $101.2^{\mathrm{c}}$ & $110.8^{\mathrm{a}}$ & $109.9^{\mathrm{a}}$ & $105.6^{\mathrm{b}}$ & $106.3^{\mathrm{b}}$ & 105.0 \\
\hline Average & & 95,6 & 99.5 & 101.6 & 103.8 & 106.3 & 101.2 & \\
\hline \multirow{5}{*}{ Second Year } & Alperbey & $86.4^{\mathrm{d}}$ & $98.2^{\mathrm{a}}$ & $101.3^{\mathrm{a}}$ & $94.6^{b}$ & $93.0^{\mathrm{bc}}$ & $90.7^{\mathrm{c}}$ & 94.0 \\
\hline & Tatlicak97 & $96.0^{c}$ & $97.0^{\mathrm{c}}$ & $100.9^{\mathrm{b}}$ & $104.9^{\mathrm{a}}$ & $98.3^{\mathrm{bc}}$ & $96.0^{c}$ & 98.9 \\
\hline & Karma2000 & $86.2^{c}$ & $91.1^{\mathrm{b}}$ & $96.1^{\mathrm{a}}$ & $97.2^{\mathrm{a}}$ & $97.3^{\mathrm{a}}$ & $95.0^{\mathrm{a}}$ & 93.8 \\
\hline & Ümranhanım & $92.6^{\mathrm{b}}$ & $93.9^{\mathrm{b}}$ & $94.9^{\mathrm{b}}$ & $92.7^{b}$ & $101.0^{\mathrm{a}}$ & $98.7^{\mathrm{a}}$ & 95.6 \\
\hline & Mikham 2002 & $97.2^{\mathrm{c}}$ & $98.2^{\mathrm{c}}$ & $98.0^{c}$ & $101.9^{b}$ & $112.8^{\mathrm{a}}$ & $110.7^{\mathrm{a}}$ & 103.1 \\
\hline \multirow{2}{*}{\multicolumn{2}{|c|}{$\begin{array}{l}\text { Average } \\
\text { General Average (dose) }\end{array}$}} & 91.7 & 95.7 & 98.2 & 98.3 & 100.5 & 98.2 & \\
\hline & & 93.7 & 97.6 & 99.9 & 101.1 & 103.4 & 99.7 & \\
\hline \multicolumn{2}{|l|}{ CV (\%): 2.07} & \multicolumn{7}{|c|}{ Mean Sq. (year $\times$ variety $\times$ fertilizer doses): $87.361 * *$} \\
\hline
\end{tabular}

*: letters indicate different groups at the $5 \%$ level

Table 3. Spike length averages of triticale treated with different doses of foliar vermicompost

\begin{tabular}{|c|c|c|c|c|c|c|c|c|}
\hline \multirow{2}{*}{ Year } & \multirow{2}{*}{ Variety } & \multicolumn{6}{|c|}{ Doses for Vermicompost $\left(\mathrm{cc} \mathrm{da}^{-1}\right)$} & \multirow{2}{*}{ Avg. } \\
\hline & & Control & 75 & 150 & 250 & 350 & 450 & \\
\hline \multirow{5}{*}{ First Year } & Alperbey & 9.06 & 9.48 & 9.39 & 9.26 & 9.66 & 9.95 & $9.47^{\mathrm{a}}$ \\
\hline & Tatlicak97 & 8.78 & 9.24 & 9.94 & 9.72 & 9.63 & 9.81 & $9.52^{\mathrm{a}}$ \\
\hline & Karma2000 & 8.89 & 8.63 & 9.30 & 9.49 & 9.91 & 9.05 & $9.21^{\mathrm{a}}$ \\
\hline & Ümranhanım & 8.50 & 8.71 & 9.33 & 9.24 & 9.40 & 9.48 & $9.11^{\mathrm{a}}$ \\
\hline & Mikham 2002 & 8.80 & 9.90 & 10.12 & 10.03 & 10.06 & 9.90 & $9.83^{\mathrm{a}}$ \\
\hline \multicolumn{2}{|l|}{ Average } & 8,81 & 9.19 & 9.62 & 9.55 & 9.73 & 9.64 & $9.43^{\mathrm{B}}$ \\
\hline \multirow{5}{*}{ Second Year } & Alperbey & 9.68 & 11.12 & 11.25 & 11.31 & 11.11 & 10.73 & $10.87^{\mathrm{a}}$ \\
\hline & Tatlicak97 & 9.35 & 9.71 & 9.60 & 10.31 & 9.45 & 10.11 & $9.76^{\mathrm{bc}}$ \\
\hline & Karma2000 & 11.43 & 9.96 & 10.60 & 10.49 & 10.54 & 10.49 & $10.59^{\mathrm{ab}}$ \\
\hline & Ümranhanım & 9.05 & 9.03 & 9.06 & 9.77 & 9.60 & 9.64 & $9.36^{\mathrm{c}}$ \\
\hline & Mikham 2002 & 9.86 & 9.71 & 9.21 & 9.53 & 9.79 & 10.56 & $9.78^{a b c}$ \\
\hline \multirow{2}{*}{\multicolumn{2}{|c|}{$\begin{array}{l}\text { Average } \\
\text { General Average (dose) }\end{array}$}} & 9.87 & 9.91 & 9.94 & 10.28 & 10.10 & 10.31 & $10.07^{\mathrm{A}}$ \\
\hline & & $9.34^{\mathrm{c}}$ & $9.55^{\mathrm{bc}}$ & $9.78^{\mathrm{ab}}$ & $9.92^{\mathrm{a}}$ & $9.92^{\mathrm{a}}$ & $9.97^{\mathrm{a}}$ & \\
\hline \multicolumn{2}{|c|}{ CV (\%): 6.77} & \multicolumn{7}{|c|}{ Mean Sq.(fertilizer doses): 1.821**; (year×variety): $87.361^{* *}$} \\
\hline
\end{tabular}

*: letters indicate different groups at the $5 \%$ level 
In his study, Günhan (2020) determined the effects of different doses of vermicompost with reduced nitrogen dose treatments on yield and yield components in Pehlivan bread wheat variety and reported that the spike length increased due to the increase in vermicompost doses at all nitrogen doses, but it was not statistically significant. Aktaş (2018) reported that vermicompost applications significantly affected both the soil properties and the wheat growth, additionally improved morphological characteristics. The vermicompost applications to the growth environments in wheat significantly affect the nutritional status of all aboveground organs. So, vermicompost can be considered a very important nutritional source for wheat growth (Barlas et al., 2018). Metabolic inhibition has not been reported in vermicompost applications. In contrast, phytohormones, enzymes and organic acids found in vermicompost can promote cell division and growth of productive organs (Levinsh 2011).

\section{Grain Number}

As seen in Table 4, the triple interaction of year $\mathrm{x}$ variety $\mathrm{x}$ vermicompost doses found to be important for the number of grains per spike, and the reactions of the varieties by years were also different. In both years, the lowest averages of grain number obtained from the control plots (33.6 and 38.0 respectively for years), and the number of grains increased by the increasing vermicompost doses. The number of grains per spike increased to the $350 \mathrm{cc} \mathrm{da}$ ${ }^{1}$ dose (avg. 44.3) in the first year and $250 \mathrm{cc} \mathrm{da}^{-1}$ dose (avg. 48.2) in the second year. Although the grain numbers generally started to decrease in the subsequent doses, the increase in average values continued when compared to the control plots. In the second year, the increase in the number of grains per spike in the Mikham 2002 variety continued till $450 \mathrm{cc} \mathrm{da}^{-1}$. Grain number per spike in triticale is one of the morphological characters that directly contribute to yield. Although generally changing depending on genotypic factors, plant height, spike length and ecological conditions that increase the number of spikelets increase the number of grains per spike (Akgün et al., 2007). In the second year, the regular rainfall and the relatively high temperatures may have caused the number of grains in spike to increase in the spring growing period. In addition, phytohormones, humic/fulvic acids found in vermicomposts can increase the number of grains by promoting flowering and pollination (Quiroz et al., 2014; Arancon et al., 2019). In the trial conducted by Günhan (2020) with bread wheat, the number of grains in the spike increased significantly due to the increased vermicompost doses in all parcels with reduced nitrogen dose, and the highest values were found at the highest doses. In another study conducted on chickpeas, the number of grains in the plant decreased at low vermicompost doses compared to control plots, while the number of plant grains increased significantly due to high doses (Uçar et al., 2020). Similarly, Ekinci et al. (2014), in their study on cucumbers, obtained an increase in the number of fruits with foliar application of liquid vermicompost. In a study conducted on petunia and geranium, more flowers appeared in plants with a combination of low dose vermicompost and high dose of biochar (Alvarez et al., 2017).

\section{Grain Yield in Spike}

Triple interaction was also found significant in grain yield in spike, and the lowest grain yield per spike averages was obtained from control plots (1.05 g and $1.01 \mathrm{~g}$ ) in 2015 and 2016 (Table 5). It was seen that the varieties and the years were affected by the vermicompost doses. Increasing fertilizer doses increased the grain yields in spike significantly. Fertilizer applications in the Alperbey variety in the first year increased the plant yield, but all the parcels treated with fertilizers were included in the same group as statistics. In general dose averages, $350 \mathrm{cc} \mathrm{da}^{-1}$ has the highest value $(1.72 \mathrm{~g})$ and $250 \mathrm{cc} \mathrm{da}^{-1}$ followed it with 1.54 g. The highest plant yield determined at $450 \mathrm{cc} \mathrm{da}^{-1}$ dose from Ümranhanım and Mikham 2002 in the first year and Mikham 2002 in the second year. In other varieties, plant yield tended to decrease after $350 \mathrm{cc} \mathrm{da}^{-1}$ (Table 5). The grain yield per spike in cereals is also one of the characters that have the highest direct effect on the grain yield as a unit, and it can vary under the effects of the genotype, environmental conditions and the nutritional status of the plant. Generally, the plant yields of the varieties with more spike length and the number of grains in spike are also high (Akgün et al., 2007). The spike length and the number of grains in spike increased up to $350 \mathrm{cc} \mathrm{da}^{-1}$ dose.

Table 4. Grain number averages of triticale treated with different doses of foliar vermicompost

\begin{tabular}{|c|c|c|c|c|c|c|c|c|}
\hline \multirow{2}{*}{ Year } & \multirow{2}{*}{ Variety } & \multicolumn{6}{|c|}{ Doses for Vermicompost $\left(\mathrm{cc} \mathrm{da}^{-1}\right)$} & \multirow{2}{*}{ Avg. } \\
\hline & & Control & 75 & 150 & 250 & 350 & 450 & \\
\hline \multirow{5}{*}{ First Year } & Alperbey & $35.0^{\mathrm{c}}$ & $42.2^{\mathrm{ab}}$ & $43.8^{\mathrm{a}}$ & $45.6^{\mathrm{a}}$ & $44.7^{\mathrm{a}}$ & $39.3^{\mathrm{b}}$ & 41.8 \\
\hline & Tatlicak97 & $32.5^{\mathrm{d}}$ & $34.5^{\mathrm{cd}}$ & $34.1^{\mathrm{cd}}$ & $41.4^{\mathrm{a}}$ & $40.1^{\mathrm{ab}}$ & $37.5^{\mathrm{bc}}$ & 36.7 \\
\hline & Karma2000 & $40.4^{\mathrm{d}}$ & $43.1^{\mathrm{cd}}$ & $42.1^{\mathrm{cd}}$ & $52.1^{\mathrm{b}}$ & $56.5^{\mathrm{a}}$ & $45.7^{\mathrm{c}}$ & 46.6 \\
\hline & Ümranhanım & $28.7^{\mathrm{b}}$ & $31.3^{\mathrm{b}}$ & $40.5^{\mathrm{a}}$ & $39.5^{\mathrm{a}}$ & $41.1^{\mathrm{a}}$ & $38.3^{\mathrm{a}}$ & 36.6 \\
\hline & Mikham 2002 & $31.5^{\mathrm{d}}$ & $37.3^{\mathrm{c}}$ & $43.2^{\mathrm{a}}$ & $40.8^{\mathrm{abc}}$ & $39.3^{\mathrm{bc}}$ & $42.0^{\mathrm{ab}}$ & 39.0 \\
\hline \multicolumn{2}{|l|}{ Average } & 33,6 & 37.7 & 40.7 & 43.9 & 44.3 & 40.6 & \\
\hline \multirow{5}{*}{ Second Year } & Alperbey & $40.3^{c}$ & $50.0^{\mathrm{a}}$ & $52.3^{\mathrm{a}}$ & $50.5^{\mathrm{a}}$ & $50.6^{\mathrm{a}}$ & $45.6^{\mathrm{b}}$ & 48.2 \\
\hline & Tatlıcak97 & $39.7^{b}$ & $43.1^{\mathrm{ab}}$ & $42.1^{\mathrm{ab}}$ & $44.3^{\mathrm{a}}$ & $42.1^{\mathrm{ab}}$ & $39.6^{\mathrm{b}}$ & 41.8 \\
\hline & Karma2000 & $39.8^{c}$ & $53.8^{\mathrm{b}}$ & $51.3^{\mathrm{b}}$ & $57.8^{\mathrm{a}}$ & $52.9^{\mathrm{b}}$ & $51.4^{\mathrm{b}}$ & 51.2 \\
\hline & Ümranhanım & $35.4^{c}$ & $39.0^{\mathrm{b}}$ & $37.5^{\mathrm{bc}}$ & $46.3^{\mathrm{a}}$ & $43.0^{\mathrm{a}}$ & $38.4^{\mathrm{bc}}$ & 39.9 \\
\hline & Mikham 2002 & $35.0^{\mathrm{c}}$ & $38.6^{\mathrm{b}}$ & $41.4^{\mathrm{ab}}$ & $42.0^{\mathrm{ab}}$ & $40.4^{\mathrm{b}}$ & $45.0^{\mathrm{a}}$ & 40.4 \\
\hline \multirow{2}{*}{\multicolumn{2}{|c|}{$\begin{array}{l}\text { Average } \\
\text { General Average (dose) }\end{array}$}} & 38.0 & 44.9 & 44.9 & 48.2 & 45.8 & 44.0 & \\
\hline & & 35.8 & 41.3 & 42.8 & 46.1 & 45.1 & 42.3 & \\
\hline \multicolumn{2}{|l|}{ CV (\%): 4.99} & \multicolumn{7}{|c|}{ Mean Sq. (year $\times$ variety $\times$ fertilizer doses): $51.100 * *$} \\
\hline
\end{tabular}

*: letters indicate different groups at the $5 \%$ level 
Table 5. Grain yield in spike averages of triticale treated with different doses of foliar vermicompost

\begin{tabular}{|c|c|c|c|c|c|c|c|c|}
\hline \multirow{2}{*}{ Year } & \multirow{2}{*}{ Variety } & \multicolumn{6}{|c|}{ Doses for Vermicompost $\left(\mathrm{cc} \mathrm{da}^{-1}\right)$} & \multirow{2}{*}{ Avg } \\
\hline & & Control & 75 & 150 & 250 & 350 & 450 & \\
\hline \multirow{5}{*}{ First Year } & Alperbey & $1.15^{\mathrm{b}}$ & $1.30^{\mathrm{a}}$ & $1.39^{\mathrm{a}}$ & $1.34^{\mathrm{a}}$ & $1.37^{\mathrm{a}}$ & $1.35^{\mathrm{a}}$ & 1.32 \\
\hline & Tatlicak97 & $1.13^{\mathrm{b}}$ & $1.14^{\mathrm{b}}$ & $1.26^{\mathrm{a}}$ & $1.32^{\mathrm{a}}$ & $1.24^{\mathrm{ab}}$ & $1.23^{\mathrm{ab}}$ & 1.22 \\
\hline & Karma2000 & $1.20^{\mathrm{c}}$ & $1.20^{\mathrm{c}}$ & $1.25^{\mathrm{c}}$ & $1.54^{\mathrm{ab}}$ & $1.61^{\mathrm{a}}$ & $1.44^{\mathrm{b}}$ & 1.37 \\
\hline & Ümranhanım & $0.85^{\mathrm{d}}$ & $0.98^{c}$ & $1.14^{\mathrm{b}}$ & $1.21^{\mathrm{ab}}$ & $1.18^{\mathrm{ab}}$ & $1.29^{\mathrm{a}}$ & 1.22 \\
\hline & Mikham 2002 & $0.92^{\mathrm{c}}$ & $1.28^{\mathrm{b}}$ & $1.35^{\mathrm{ab}}$ & $1.32^{\mathrm{b}}$ & $1.36^{\mathrm{ab}}$ & $1.45^{\mathrm{a}}$ & 1.28 \\
\hline \multicolumn{2}{|l|}{ Average } & 1,05 & 1.18 & 1.28 & 1.35 & 1.48 & 1.35 & \\
\hline \multirow{5}{*}{ Second Year } & Alperbey & $1.24^{\mathrm{d}}$ & $1.97^{c}$ & $2.30^{\mathrm{a}}$ & $2.19^{\mathrm{b}}$ & $2.16^{\mathrm{b}}$ & $1.97^{\mathrm{c}}$ & 1.97 \\
\hline & Tatlicak97 & $0.75^{\mathrm{d}}$ & $0.88^{c}$ & $1.05^{\mathrm{b}}$ & $1.39^{\mathrm{a}}$ & $1.28^{\mathrm{a}}$ & $0.83^{\mathrm{cd}}$ & 1.03 \\
\hline & Karma2000 & $1.61^{\mathrm{d}}$ & $1.92^{\mathrm{c}}$ & $2.51^{\mathrm{b}}$ & $2.70^{\mathrm{a}}$ & $1.83^{\mathrm{c}}$ & $1.87^{\mathrm{c}}$ & 2.07 \\
\hline & Ümranhanım & $0.77^{\mathrm{d}}$ & $0.78^{d}$ & $1.12^{\mathrm{bc}}$ & $1.13^{\mathrm{b}}$ & $1.37^{\mathrm{a}}$ & $1.01^{\mathrm{c}}$ & 1.03 \\
\hline & Mikham 2002 & $0.69^{\mathrm{e}}$ & $1.02^{\mathrm{d}}$ & $0.95^{\mathrm{d}}$ & $1.19^{c}$ & $1.59^{\mathrm{b}}$ & $1.77^{\mathrm{a}}$ & 1.20 \\
\hline \multirow{2}{*}{\multicolumn{2}{|c|}{$\begin{array}{l}\text { Average } \\
\text { General Average (dose) }\end{array}$}} & 1.01 & 1.31 & 1.59 & 1.72 & 1.65 & 1.49 & \\
\hline & & 1.03 & 1.25 & 1.44 & 1.54 & 1.57 & 1.42 & \\
\hline \multicolumn{2}{|l|}{ CV (\%): 4.81} & \multicolumn{7}{|c|}{ Mean Sq. (year $\times$ variety $\times$ fertilizer doses): $): 0.239 * *$} \\
\hline
\end{tabular}

*: letters indicate different groups at the $5 \%$ level

Table 6. Thousand-grain weight averages of triticale treated with different doses of foliar vermicompost

\begin{tabular}{|c|c|c|c|c|c|c|c|c|}
\hline \multirow{2}{*}{ Year } & \multirow{2}{*}{ Variety } & \multicolumn{6}{|c|}{ Doses for Vermicompost $\left(\mathrm{cc} \mathrm{da}^{-1}\right)$} & \multirow{2}{*}{ Avg. } \\
\hline & & Control & 75 & 150 & 250 & 350 & 450 & \\
\hline \multirow{5}{*}{ First Year } & Alperbey & 32.06 & 31.07 & 32.56 & 30.72 & 29.52 & 29,49 & $30.90^{\mathrm{ab}}$ \\
\hline & Tatlıcak97 & 32.19 & 30.65 & 32.62 & 31.35 & 31.06 & 29,30 & $31.20^{\mathrm{ab}}$ \\
\hline & Karma2000 & 26.47 & 26.25 & 30.69 & 29.00 & 29.79 & 27,63 & $28.31^{\mathrm{b}}$ \\
\hline & Ümranhanım & 30.92 & 33.23 & 32.23 & 30.96 & 29.45 & 30,06 & $31.14^{\mathrm{ab}}$ \\
\hline & Mikham 2002 & 33.15 & 32.38 & 31.38 & 34.04 & 33.31 & 34,21 & $33.08^{\mathrm{a}}$ \\
\hline \multicolumn{2}{|l|}{ Average } & $30.96^{\mathrm{ab}}$ & $30.72^{\mathrm{ab}}$ & $31.90^{\mathrm{a}}$ & $31.21^{\mathrm{ab}}$ & $30.63^{\mathrm{ab}}$ & $30.14^{\mathrm{b}}$ & $30.93^{\mathrm{B}}$ \\
\hline \multirow{5}{*}{ Second Year } & Alperbey & 40.85 & 45.05 & 46.03 & 42.33 & 41.07 & 40,96 & $42.72^{\mathrm{a}}$ \\
\hline & Tatlıcak97 & 24.40 & 28.14 & 31.63 & 34.98 & 33.76 & 31,98 & $30.81^{\mathrm{c}}$ \\
\hline & Karma2000 & 38.10 & 40.87 & 42.04 & 41.24 & 40.87 & 40,00 & $40.52^{\mathrm{a}}$ \\
\hline & Ümranhanım & 30.08 & 37.97 & 35.97 & 39.88 & 35.44 & 36,95 & $36.05^{\mathrm{b}}$ \\
\hline & Mikham 2002 & 38.68 & 38.67 & 38.33 & 39.15 & 38.79 & 40,55 & $39.03^{\mathrm{ab}}$ \\
\hline \multirow{2}{*}{\multicolumn{2}{|c|}{$\begin{array}{l}\text { Average } \\
\text { General Average (dose) }\end{array}$}} & $34.42^{\mathrm{c}}$ & $38.18^{\mathrm{ab}}$ & $38.80^{\mathrm{ab}}$ & $39.52^{\mathrm{a}}$ & $38.00^{\mathrm{b}}$ & $38.09^{\mathrm{b}}$ & $37.83^{\mathrm{A}}$ \\
\hline & & 32.69 & 34.43 & 35.35 & 35.51 & 34.31 & 33.97 & \\
\hline \multicolumn{2}{|c|}{ CV $(\%): 6.93$} & \multicolumn{7}{|c|}{$\begin{array}{c}\text { Mean Sq. (year } \times \text { variety): } 248.060^{* * ;} \text { (year } \times \text { fertilizer doses): } 23.548^{* *} ; \\
\left(\text { variety } \times \text { fertilizer doses): } 11.266^{*}\right.\end{array}$} \\
\hline
\end{tabular}

The highest averages were obtained with $450 \mathrm{cc} \mathrm{da}^{-1}$ dose for Ümranhanım and Mikham 2002 varieties in the first year and for Mikham 2002 for the second year. This result can be explained by the high weight of a thousandgrain in $450 \mathrm{cc} \mathrm{da}^{-1}$ plots. Although it varies with the doses and the genotype, many active substances found in both solid and liquid vermicompost are effective in the early stages of plant growth, starting from seed germination. Especially humic and phenolic compounds can affect plant growth and yield (Levinsh, 2011). During the production of vermicompost, there is a very complex interaction between worms and other microorganisms (Arancon et al., 2012). It is known that many microorganisms secrete plant hormone-like substances and direct worm products in vermicomposts. Vermicomposts contain auxin and cytokinin-like compounds that stimulate plant growth and development in large proportions (Levinsh 2011; Quiroz et al., 2014; Arancon et al., 2019). Consequently, it is thought that the yield values per plant have increased by the applications of $250 \mathrm{cc} \mathrm{da}-1$ and $350 \mathrm{cc} \mathrm{da}^{-1}$.

\section{Thousand Grain Weight}

Year $\times$ variety, year $\times$ fertilizer dose and variety $\times$ fertilizer dose interactions found to be significant for thousand-grain weight. Although the $150 \mathrm{cc}$ da- 1 has a $31.90 \mathrm{~g}$ average in the first year, grain weights decreased by increasing doses (Table 6). The grain weight values were not statistically significant and they fell below the control group in the first year, except 150 and $250 \mathrm{cc} \mathrm{da}^{-1}$. The increase in grain weight up to the dose of $250 \mathrm{cc} \mathrm{da}^{-1}$ and tended to decrease in the $350 \mathrm{cc} \mathrm{da}^{-1}$ and $450 \mathrm{cc} \mathrm{da}^{-1}$ doses in the second year. Alperbey variety had the highest grain weight average of two years. Second-year data were higher, mainly because of precipitation and temperature. Especially extending milk and soft dough stages directly related to the precipitations taken in May and June affect the weight of grains in overall and the observed higher second-year values, possibly, can be explained by this way. When the interaction of the variety $\times$ vermicompost doses evaluated, it was seen that the response of Alperbey and Mikham 2002 was not significant for the thousand-grain weight (Table 7). On the other hand, in Tatlıcak 97, Karma 
2000 and Ümranhanım varieties, the lowest grain weights were determined in the control group in the second year, and vermicompost applications increased the grain weights depending on the varieties. In these varieties, the grain weights increased significantly at low doses of vermicompost but the differences between vermicompost doses were not found to be statistically significant (Table 7).

Thousand-grain weight is an important character used in determining both seed and product quality as well as contributing to the total yield of cereals. Although it varies depending on the genotypes, it may also change by the environmental conditions and cultivation techniques. For example, in a study conducted in Isparta province, Akgün et al. (2007) reported that the year $\times$ genotype interactions in triticale were important due to the variable responses of genotypes to environmental conditions, and the grain weight varied between 34.3-42.4 g depending on the variety. Thousand-grain weight increased significantly in a study where vermicompost and poultry manure mixtures applied to wheat, (Gowda et al., 2008). In another study on wheat, it was reported that the combination of vermicompost and phosphorus fertilizer gave the highest yield and thousand-grain weight (Cheraghi et al., 2016). Günhan (2020) determined that the thousand-grain weight of Pehlivan bread wheat variety increased relatedly the increase in vermicompost doses in reduced $\mathrm{N}$ fertilizer in wheat. In another study conducted on chickpeas, the low dose of vermicompost did not affect the one thousand-grain weight, but increased significantly at high doses (Uçar et al., 2020).

\section{Grain Yield Per Decare}

The interaction of year $\times$ variety $\times$ fertilizer dose found to be statistically significant in unit area grain yield, and the responses of the varieties differed by the years (Table 8). The lowest yields obtained in the control parcels in both years (349.8 and $331.2 \mathrm{~kg} \mathrm{da}^{-1}$, respectively). For all varieties, the grain yield averages increased with the increase of vermicompost doses in both years. Different degrees of variety were found between vermicompost doses in each of the years. When evaluated the variety averages, significant increases were observed in grain yields up to $250 \mathrm{cc} \mathrm{da}^{-1}$ fertilizer dose in both years. However, an overall downward trend started after this dose. Significant decreases were obtained in some varieties, especially, at the doses between 150-350 cc da-1 (Table 8). To the overall averages of the doses by two years, second-year grain yield $\left(440,46 \mathrm{~kg} \mathrm{da}^{-1}\right)$ was higher than the first year
(436,78 $\left.\mathrm{kg} \mathrm{da}^{-1}\right)$ values. This can be relatable with both precipitation and temperature values during the growing period, especially at the dough stages. that the second-year growing period was warmer $8.8 \%$ than the first year. Additionally, spike length, grain weight and grain number per spike measurements also support this result depending on the meteorological measurements. In both years the grain yield increased to approximately $32 \%$ in the first year and $43 \%$ in the second year in the parcels where the $150 \mathrm{cc}$ $\mathrm{da}^{-1}$ dose was applied, compared to the control parcels. Grain yield per unit in triticale largely depends on the genotypic structure. However, during the growing period, it may also change in the environmental conditions such as light, temperature, precipitation and humidity and agronomic processes (Akgün et al., 2007). As in the previous morphological characters, the distribution of total rainfall and months during the vegetation period, especially in the spring period, the number of plants per unit area and the tillering potential affect the grain development, so the grain yield can also be positively affected. Wheat and barley yields can be obtained with equal or higher yields by providing the ideal plant density per unit area in triticale. Thus, it is important to determine the most suitable cultivation techniques for the varieties (Demir et al., 1981; Yağbasanlar et al., 1989; Tosun et al., 2000; Akgün et al., 2007). In the study investigating the effects of vermicompost doses on reduced nitrogen fertilization in Pehlivan bread wheat variety in Bursa conditions, vermicompost caused an increase in grain yield per decare with no nitrogen fertilizer (Günhan, 2020). Uçar et al. (2020) reported that the lowest grain yields were obtained from control plots in chickpeas and the highest yield was detected in $120 \mathrm{~kg} \mathrm{da}^{-1}$ vermicompost with increasing doses. Although top fertilizer was not used, vermicompost applications significantly increased the yield. Similar to our findings, Arancon et al. (2019) reported in their trials on lettuce and tomatoes under hydroponic conditions that even very low doses of vermicompost increased yield when nutrient solutions were reduced by $25 \%$ and $50 \%$. Plant growth and grain yield may sometimes increase with non-nutritional reactions with vermicompost applications. In additions to plant nutrients, vermicompost can contain some phytohormones, enzymes and organic acids. Plant growth parameters can be positively affected even at low doses of these substances. Vermicompost contains not only worm products but also metabolites secreted by many microorganisms (Levinsh, 2011).

Table 7. Thousand-grain weight averages of triticale treated with different doses of foliar vermicompost (continue)

\begin{tabular}{|c|c|c|c|c|c|c|c|}
\hline \multirow{2}{*}{ Variety } & \multicolumn{6}{|c|}{ Doses for Vermicompost $\left(\mathrm{cc} \mathrm{da}^{-1}\right)$} & \multirow{2}{*}{ Avg. } \\
\hline & Control & 75 & 150 & 250 & 350 & 450 & \\
\hline Alperbey & $36.46^{\mathrm{a}}$ & $38.06^{\mathrm{a}}$ & $39.30^{\mathrm{a}}$ & $36.53^{\mathrm{a}}$ & $35.29^{\mathrm{a}}$ & $35.22^{\mathrm{a}}$ & $36.81^{\mathrm{a}}$ \\
\hline Tatlicak97 & $28.30^{\mathrm{b}}$ & $29.39^{\mathrm{ab}}$ & $32.12^{\mathrm{ab}}$ & $33.17^{\mathrm{a}}$ & $32.41^{\mathrm{ab}}$ & $30.64^{\mathrm{ab}}$ & $31.01^{\mathrm{b}}$ \\
\hline Karma2000 & $32.28^{\mathrm{b}}$ & $33.56^{\mathrm{ab}}$ & $36.37^{\mathrm{a}}$ & $35.12^{\mathrm{ab}}$ & $35.33^{\mathrm{ab}}$ & $33.82^{\mathrm{ab}}$ & $34.41^{\mathrm{ab}}$ \\
\hline Ümranhanım & $30.50^{\mathrm{b}}$ & $35.60^{\mathrm{a}}$ & $34.10^{\mathrm{ab}}$ & $35.42^{\mathrm{a}}$ & $32.45^{\mathrm{ab}}$ & $33.51^{\mathrm{ab}}$ & $33.60^{\mathrm{ab}}$ \\
\hline Mikham 2002 & $35.92^{\mathrm{a}}$ & $35.52^{\mathrm{a}}$ & $34.86^{\mathrm{a}}$ & $37.30^{\mathrm{a}}$ & $36.05^{\mathrm{a}}$ & $36.68^{a}$ & $36.05^{\mathrm{a}}$ \\
\hline Average & $32,69^{\mathrm{c}}$ & $34,43^{\mathrm{ab}}$ & $35,35^{\mathrm{a}}$ & $35,51^{\mathrm{a}}$ & $34,31^{\mathrm{ab}}$ & $33,97^{\mathrm{b}}$ & $32,69^{\mathrm{c}}$ \\
\hline CV (\%): 6.93 & \multicolumn{7}{|c|}{$\begin{array}{c}\text { Mean Sq. (year } \times \text { variety): } 248.060 * * ;(\text { year } \times \text { fertilizer doses }): 23.548^{* *} ; \text { (variety } \times \text { fertilize } 1 \\
\text { doses }): 11.266^{*}\end{array}$} \\
\hline
\end{tabular}

*: letters indicate different groups at the $5 \%$ level 
Table 8. Grain yield per decare averages of triticale treated with different doses of foliar vermicompost

\begin{tabular}{|c|c|c|c|c|c|c|c|c|}
\hline \multirow{2}{*}{ Year } & \multirow{2}{*}{ Variety } & \multicolumn{6}{|c|}{ Doses for Vermicompost $\left(\mathrm{cc} \mathrm{da}^{-1}\right)$} & \multirow{2}{*}{ Avg. } \\
\hline & & Control & 75 & 150 & 250 & 350 & 450 & \\
\hline \multirow{5}{*}{ First Year } & Alperbey & $320.3^{\mathrm{c}}$ & $404.3^{\mathrm{b}}$ & $475.7^{\mathrm{a}}$ & $452.3^{\mathrm{a}}$ & $465.0^{\mathrm{a}}$ & $377.7^{b}$ & 415.9 \\
\hline & Tatlicak97 & $351.0^{\mathrm{e}}$ & $387.3^{\mathrm{d}}$ & $464.3^{\mathrm{a}}$ & $449.0^{\mathrm{ab}}$ & $425.3^{\mathrm{bc}}$ & $411.7^{\mathrm{cd}}$ & 414.8 \\
\hline & Karma2000 & $338.0^{\mathrm{d}}$ & $376.7^{\mathrm{c}}$ & $481.7^{\mathrm{a}}$ & $444.3^{\mathrm{b}}$ & $455.0^{\mathrm{b}}$ & $398.0^{c}$ & 415.6 \\
\hline & Ümranhanım & $356.3^{\mathrm{b}}$ & $411.3^{\mathrm{a}}$ & $410.0^{\mathrm{a}}$ & $400.3^{\mathrm{a}}$ & $421.3^{\mathrm{a}}$ & $373.0^{\mathrm{b}}$ & 395.4 \\
\hline & Mikham 2002 & $383.3^{\mathrm{d}}$ & $487.7^{\mathrm{b}}$ & $470.3^{\mathrm{bc}}$ & $536.3^{\mathrm{a}}$ & $488.3^{\mathrm{b}}$ & $452.3^{\mathrm{c}}$ & 469.7 \\
\hline \multicolumn{2}{|l|}{ Average } & 349.8 & 413.5 & 460.4 & 456.5 & 451.0 & 402.5 & \\
\hline \multirow{5}{*}{ Second Year } & Alperbey & $337.4^{\mathrm{e}}$ & $642.3^{b}$ & $769.3^{\mathrm{a}}$ & $575.7^{c}$ & $514.0^{\mathrm{d}}$ & $493.2^{\mathrm{d}}$ & 555.3 \\
\hline & Tatlicak97 & $311.1^{\mathrm{d}}$ & $347.3^{b c}$ & $358.5^{\mathrm{ab}}$ & $363.3^{\mathrm{ab}}$ & $375.7^{a}$ & $329.3^{\mathrm{cd}}$ & 347.5 \\
\hline & Karma2000 & $446.7^{c}$ & $458.5^{\mathrm{bc}}$ & $522.1^{\mathrm{a}}$ & $480.6^{\mathrm{b}}$ & $465.1^{b c}$ & $455.0^{\mathrm{bc}}$ & 471.3 \\
\hline & Ümranhanım & $234.3^{\mathrm{d}}$ & $317.2^{c}$ & $364.3^{\mathrm{b}}$ & $392.7^{\mathrm{a}}$ & $394.8^{a}$ & $307.6^{c}$ & 335.2 \\
\hline & Mikham 2002 & $326.4^{\mathrm{d}}$ & $357.3^{\mathrm{c}}$ & $365.7^{\mathrm{c}}$ & $426.5^{\mathrm{b}}$ & $442.4^{\mathrm{b}}$ & $493.3^{\mathrm{a}}$ & 401.9 \\
\hline \multirow{2}{*}{\multicolumn{2}{|c|}{$\begin{array}{l}\text { Average } \\
\text { General Average (dose) }\end{array}$}} & 331.2 & 424.5 & 476.0 & 447.7 & 438.4 & 415.7 & \\
\hline & & 340.5 & 419 & 468.2 & 452.1 & 444.7 & 409.1 & \\
\hline \multicolumn{2}{|l|}{ CV (\%): 3.65} & \multicolumn{7}{|c|}{ Mean Sq. (year $\times$ variety $\times$ fertilizer doses): $6637.843^{* *}$} \\
\hline
\end{tabular}

*: letters indicate different groups at the $5 \%$ level

Vermicompost include Auxin (IAA), Cytokinin (isopentyladenosine, isopentyladenine) and Gibberellic acids (GA4, GA24 and GA34) group phytohormones (Arancon et al., 2012). Humic-fulvic acids contained in vermicompost bind the minerals necessary for the plants and allow these substances to reach the plants slowly during their dissolution, or by binding to certain receptors in the plant, humic substances can improve the signalling systems and enable enzyme synthesis and activation. Due to enzyme activation, the harmful effects of reactive oxygen species can be eliminated, the membrane stability index and the chlorophyll content may increase. Thus, plant growth may also be positively affected (Levinsh, 2011; Arancon et al., 2012; Arancon et al., 2019; Mamnabi et al., 2020). In studies on different plants, photosynthetic activity increased due to the increase in chlorophyll content with the intake of phytohormones and organic acids that stimulate plant growth with vermicompost application (Levinsh, 2011). In addition, $\mathrm{NO}_{3}$ assimilation has been accelerated by the increase in nitrate reductase enzyme activity, especially in plant species that cannot fix nitrogen. So, plant growth characteristics and yield can be positively affected (Özen and Onay, 2007).

In the study, grain yield values tended to decrease at higher doses. This situation can be explained in two ways. First of all, if the plant nutrients are applied from the leaves, the nutrient solution must be present in a thin layer on the leaf surface. Additionally, nutrient intake in foliar fertilization can continue between 1 hour to 10-15 days depending on the plant species and nutrients. Therefore, due to the rapid evaporation of the water in the solution in hot and sunny weather, the salts remaining on the leaf surface may have a toxic effect (Kacar and Katkat, 2018). Secondly, during the production of solid or liquid vermicomposts, insoluble and plant growth-inhibiting substances may have accumulated. It has also been presented that some phenolic compounds accumulate during vermicompost production. Phenolic compounds such as gallic acid and chlorogenic acid can inhibit seed germination, plant growth, and chlorophyll synthesis in the plant (Levinsh, 2011). Due to the occurrence of this interaction, yield may be reduced, especially when high doses of vermicompost are used.

\section{Harvest Index}

As viewed in Table 9, year $\times$ variety $\times$ fertilizer dose interaction was found to be significant for harvest index. By the years, the reactions of the varieties to the doses have differed. As the average of the varieties, the lowest harvest index averages were determined in the control plots in both years $(28.4 \%$ and $31.5 \%$, respectively). The effect of vermicompost doses on the harvest index was insignificant for Karma2000 and Ümranhanım varieties in the first year and Karma 2000 in the second year, and similar values were obtained as in the control plots. The harvest index, which increased up to $350 \mathrm{cc} \mathrm{da}^{-1}$ dose in 2015 and $250 \mathrm{cc}$ $\mathrm{da}^{-1}$ dose in 2016, in other varieties tended to decrease with increasing doses. Generally, higher harvest index rates were obtained in the second year due to the excess of spring precipitation.

Harvest index is the ratio of grain yield to total biomass. Factors affecting the increase in grain yield also increase the harvest index. It is emphasized that there is a positive correlation between grain yield and grain number and weight per spike. The harvest index also increases when the unit volume weight of the grain and the grain weight are high. In a study conducted in Erzurum, the harvest index varied between $21-36.1 \%$, similar to our results, and significant variations were determined by years (Akgün et al., 1997; Tosun et al., 2000).

As affirmed in the studies conducted on many plants, it has shown that the solid or liquid vermicompost application affects the plant growth positively and the dry matter yield increases (Arancon et al., 2012; Rostami et al., 2014; Morales-Cort et al., 2018; Mamnabi et al., 2020).

\section{Protein Contents}

Depending on Table 10, the lowest protein content values in both years were determined in control plots. Although varied by the years and the varieties, the grain protein contents increased significantly. These increases continued up to the $150 \mathrm{cc} \mathrm{da}{ }^{-1}$ in the first year and $250 \mathrm{cc}$ $\mathrm{da}^{-1}$ in the second year as the variety averages. The highest protein content was found to be $9.72 \%$ at $150 \mathrm{cc} \mathrm{da}^{-1}$ in the first year and $10.86 \%$. at $250 \mathrm{cc} \mathrm{da}^{-1}$ in the second year. Generally, protein ratios in the second year were higher than in the first year. As known usually, plant protein 
content is dependent on nitrogen accumulation mainly in the milk stage in cereals, which generally starts that in the last half of May at our region. When the precipitation measurements inspected, especially in the firs-year precipitation in June was rather higher than the second year and this may cause to be the promoting of vegetative development and delaying of initializing the milk stage. On the other hand, in the second year, May precipitation was excessive but June was below than both long term and first year, and additionally, June was warmer about $2.5^{\circ} \mathrm{C}$ than the first year that, maybe, supported the nitrogen accumulation in grain at the milk stage by providing extra time. The protein content is a crucial quality criterion and varies to the genotype, environmental conditions and cultural processes by the growth technique. Similar to the results, the protein content in triticale varied according to years and genotypes in a study under Isparta conditions (Akgün et al., 2007). In general, vermicompost doses increased the grain protein content. Indeed, Quiroz et al. (2014) stated in their study on tomatoes that due to the increase in chlorophyll content and nitrate reductase enzyme activity in plants containing vermicompost, $\mathrm{NO}_{3}$ assimilation and the organic $\mathrm{N}$ content in the leaves increased significantly. In another study conducted on wheat (Barlas et al., 2018), the plant nitrogen content increased significantly with vermicompost applications. In a study on rape, vermicompost increased the enzyme activity and chlorophyll content in the plant, and plant growth and product quality increased due to the increase in membrane stability index and stomatal conductivity (Mamnabi et al., 2020).

Table 9. Harvest index averages of triticale treated with different doses of foliar vermicompost

\begin{tabular}{|c|c|c|c|c|c|c|c|c|}
\hline \multirow{2}{*}{ Year } & \multirow{2}{*}{ Variety } & \multicolumn{6}{|c|}{ Doses for Vermicompost $\left(\mathrm{cc} \mathrm{da}^{-1}\right)$} & \multirow{2}{*}{ Avg. } \\
\hline & & Control & 75 & 150 & 250 & 350 & 450 & \\
\hline \multirow{5}{*}{ First Year } & Alperbey & $28.9^{\mathrm{b}}$ & $28.9^{\mathrm{b}}$ & $33.1^{\mathrm{a}}$ & $34.6^{\mathrm{a}}$ & $34.0^{\mathrm{a}}$ & $33.4^{\mathrm{a}}$ & 32.1 \\
\hline & Tatlicak97 & $29.4^{\mathrm{b}}$ & $29.7^{\mathrm{b}}$ & $30.9^{\mathrm{ab}}$ & $32.0^{\mathrm{ab}}$ & $31.2^{\mathrm{ab}}$ & $33.8^{\mathrm{a}}$ & 31.2 \\
\hline & Karma2000 & $26.3^{\mathrm{a}}$ & $27.0^{\mathrm{a}}$ & $29.1^{\mathrm{a}}$ & $29.4^{\mathrm{a}}$ & $29.5^{\mathrm{a}}$ & $26.8^{\mathrm{a}}$ & 28.1 \\
\hline & Ümranhanım & $28.1^{\mathrm{a}}$ & $29.1^{\mathrm{a}}$ & $29.3^{\mathrm{a}}$ & $29.5^{\mathrm{a}}$ & $30.3^{\mathrm{a}}$ & $31.0^{\mathrm{a}}$ & 29.5 \\
\hline & Mikham 2002 & $29.1^{\mathrm{b}}$ & $31.4^{\mathrm{ab}}$ & $30.9^{\mathrm{ab}}$ & $32.1^{\mathrm{ab}}$ & $32.9^{\mathrm{a}}$ & $31.5^{\mathrm{ab}}$ & 31.3 \\
\hline \multicolumn{2}{|l|}{ Average } & 28.4 & 29.2 & 30.7 & 31.5 & 31.6 & 31.3 & \\
\hline \multirow{5}{*}{ Second Year } & Alperbey & $30.6^{\mathrm{c}}$ & $36.2^{\mathrm{ab}}$ & $37.0^{\mathrm{ab}}$ & $39.1^{\mathrm{a}}$ & $32.9^{\mathrm{bc}}$ & $31.8^{\mathrm{c}}$ & 34.6 \\
\hline & Tatlicak97 & $25.8^{\mathrm{b}}$ & $29.8^{\mathrm{a}}$ & $31.5^{\mathrm{a}}$ & $32.7^{\mathrm{a}}$ & $31.5^{\mathrm{a}}$ & $31.6^{\mathrm{a}}$ & 30.5 \\
\hline & Karma2000 & $32.4^{\mathrm{a}}$ & $33.4^{\mathrm{a}}$ & $33.4^{\mathrm{a}}$ & $33.2^{\mathrm{a}}$ & $33.1^{\mathrm{a}}$ & $33.4^{\mathrm{a}}$ & 33.2 \\
\hline & Ümranhanım & $26.3^{b}$ & $29.4^{\mathrm{ab}}$ & $29.4^{\mathrm{ab}}$ & $31.4^{\mathrm{a}}$ & $31.7^{\mathrm{a}}$ & $30.2^{\mathrm{a}}$ & 29.7 \\
\hline & Mikham 2002 & $26.3^{\mathrm{d}}$ & $28.8^{\mathrm{cd}}$ & $28.4^{\mathrm{c}} \mathrm{d}$ & $34.1^{\mathrm{ab}}$ & $34.3^{\mathrm{a}}$ & $31.1^{\mathrm{bc}}$ & 30.5 \\
\hline \multirow{2}{*}{\multicolumn{2}{|c|}{$\begin{array}{l}\text { Average } \\
\text { General Average (dose) }\end{array}$}} & 31.5 & 32.0 & 34.1 & 32.7 & 31.6 & 28.3 & \\
\hline & & 29.9 & 30.6 & 32.4 & 32.1 & 31.6 & 29.8 & \\
\hline \multicolumn{2}{|l|}{ CV (\%): 6.10} & \multicolumn{6}{|c|}{ Mean Sq. (year $\times$ variety $\times$ fertilizer doses): $6.292 *$} & \\
\hline
\end{tabular}

*: letters indicate different groups at the $5 \%$ level

Table 10. Protein contents averages of triticale treated with different doses of foliar vermicompost

\begin{tabular}{|c|c|c|c|c|c|c|c|c|}
\hline \multirow{2}{*}{ Year } & \multirow{2}{*}{ Variety } & \multicolumn{6}{|c|}{ Doses for Vermicompost $\left(\mathrm{cc} \mathrm{da}^{-1}\right)$} & \multirow{2}{*}{ Avg. } \\
\hline & & Control & 75 & 150 & 250 & 350 & 450 & \\
\hline \multirow{5}{*}{ First Year } & Alperbey & $7.49^{\mathrm{c}}$ & $8.72^{\mathrm{b}}$ & $10.79^{\mathrm{a}}$ & $7.90^{\mathrm{b}}$ & $8.71^{\mathrm{b}}$ & $8.68^{b}$ & 8.72 \\
\hline & Tatlicak97 & $7.99^{c}$ & $8.94^{\mathrm{b}}$ & $8.24^{\mathrm{c}}$ & $8.33^{\mathrm{c}}$ & $9.02^{\mathrm{b}}$ & $10.29^{\mathrm{a}}$ & 8.80 \\
\hline & Karma2000 & $9.11^{\mathrm{b}}$ & $10.20^{\mathrm{a}}$ & $10.06^{\mathrm{a}}$ & $10.15^{\mathrm{a}}$ & $10.04^{\mathrm{a}}$ & $9.33^{\mathrm{b}}$ & 9.82 \\
\hline & Ümranhanım & $7.97^{\mathrm{d}}$ & $8.2 \mathrm{~d}$ & $10.40^{\mathrm{b}}$ & $11.01^{\mathrm{a}}$ & $9.67^{\mathrm{c}}$ & $8.06^{\mathrm{d}}$ & 9.22 \\
\hline & Mikham 2002 & $8.82^{\mathrm{c}}$ & $9.05^{\mathrm{c}}$ & $9.13^{\mathrm{c}}$ & $9.91^{\mathrm{ab}}$ & $10.19^{\mathrm{a}}$ & $9.80^{\mathrm{b}}$ & 9.48 \\
\hline \multicolumn{2}{|l|}{ Average } & 8.28 & 9.02 & 9.72 & 9.46 & 9.53 & 9.23 & \\
\hline \multirow{5}{*}{ Second Year } & Alperbey & $7.80^{c}$ & $9.62^{\mathrm{b}}$ & $9.83^{\mathrm{b}}$ & $11.69^{\mathrm{a}}$ & $9.64^{b}$ & $9.63^{b}$ & 9.70 \\
\hline & Tatlicak97 & $7.29^{\mathrm{d}}$ & $8.59^{c}$ & $8.89^{c}$ & $9.56^{\mathrm{b}}$ & $10.82^{\mathrm{a}}$ & $9.66^{\mathrm{b}}$ & 9.14 \\
\hline & Karma2000 & $9.93^{\mathrm{b}}$ & $10.95^{\mathrm{a}}$ & $10.86^{\mathrm{a}}$ & $10.97^{\mathrm{a}}$ & $10.86^{\mathrm{a}}$ & $10.20^{\mathrm{b}}$ & 10.63 \\
\hline & Ümranhanım & $8.77^{\mathrm{d}}$ & $8.69^{d}$ & $10.60^{c}$ & $11.03^{\mathrm{b}}$ & $11.60^{\mathrm{a}}$ & $8.87^{\mathrm{d}}$ & 9.93 \\
\hline & Mikham 2002 & $9.78^{\mathrm{c}}$ & $10.03^{\mathrm{c}}$ & $10.65^{\mathrm{b}}$ & $11.06^{\mathrm{a}}$ & $10.83^{\mathrm{ab}}$ & $10.02^{\mathrm{c}}$ & 10.40 \\
\hline \multirow{2}{*}{\multicolumn{2}{|c|}{$\begin{array}{l}\text { Average } \\
\text { General Average (dose) }\end{array}$}} & 8.71 & 9.58 & 10.17 & 10.86 & 10.75 & 9.68 & \\
\hline & & 8.50 & 9.30 & 9.95 & 10.16 & 10.14 & 9.46 & \\
\hline \multicolumn{2}{|l|}{ CV (\%): 2.13} & \multicolumn{7}{|c|}{ Mean Sq. (year $\times$ variety $\times$ fertilizer doses): $0.931 * *$} \\
\hline
\end{tabular}

*: letters indicate different groups at the $5 \%$ level

\section{Results}

Approximately $90 \%$ of the organic matter content of the soils in our country is either very low or in a lower class. Hence, the nutrient deficiencies in the soil are tried to be overcome by appropriate fertilization. Nitrogen is one of the most needed nutrients to increase grain yield per unit in agriculture. However, approximately half of the nitrogen used in agriculture cannot be taken by plants. This nitrogen can negatively affect beneficial microorganisms in the soil. In addition, it may cause environmental problems and severe detriment effects on human health by causing 
pollution of water resources and nitrate accumulation in drinking water (Sönmez et al., 2008; Sönmez and Çı̆̆ 2019; Karaşahin, 2014). Therefore, there is a need for new approaches that do not reduce productivity and cause environmental problems. Additionally, people's demand for organic agricultural products is also increasing. In parallel with the increasing consumer demands and increasing environmental problems, the use of organic products in plant nutrition is increasing in recent years, and such products with very different ingredients and names are taking places in the markets. To benefit from organic fertilizers at the highest level, the reactions of these fertilizers in soils and their effects on plant growth should be examined from different aspects. In many studies conducted in our country, it has been presented that vermicompost can be used in our soils as an organic fertilizer, and in this context, it will have substantial benefits for both farmers and the environment.

This study was carried out to determine the effects of different doses of liquid vermicompost fertilizer on the yield and some yield characteristics of triticale varieties with no nitrogen as top fertilizer in Kirıkkale University, Delice Vocational School fields. For this purpose, plant height, spike length, number of grains in spike and grain yield, thousand-grain weight, grain yield per decare, harvest index and protein ratio were examined in triticale.

As stated in the results, the lowest averages in triticale varieties were determined in control plots. Yield and morphological characteristics increased significantly depending on the increasing vermicompost doses in all characteristics. However, the responses of triticale varieties to vermicompost applications differed as per to the investigated factors. As an average of years and varieties, increases were observed up to $350 \mathrm{cc} \mathrm{da}^{-1}$ dose in plant height, spike length and grain yield in spike in vermicompost applications, and up to $250 \mathrm{cc} \mathrm{da}^{-1}$ in spike number, thousand-grain weight, grain yield per decare, harvest index and protein ratio. All of the characteristics tended to decrease averagely at the highest dose of $450 \mathrm{cc}$ $\mathrm{da}^{-1}$ vermicompost. For the grain yield per unit area, it was observed that a satisfactory yield could be obtained by applying $250 \mathrm{cc} \mathrm{ha}^{-1}$ vermicompost without nitrogenous fertilizers.

\section{Conclusion}

It is thought that the use of vermicompost as an organic liquid fertilizer in soils with insufficient organic matter content will be beneficial in terms of both productivity and quality increase and sustainable soil and environmental health. In this respect, it can be suggested that

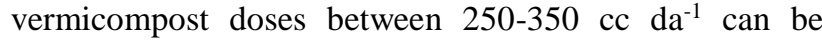
applied for triticale under Central Anatolia conditions.

\section{References}

Akgün İ, Kaya M, Altındal D. 2007. Isparta Ekolojik Koşullarında Bazı Tritikale Hat/Çeşitlerinin Verim ve Verim Unsurlarının Belirlenmesi. Akdeniz Üniversitesi Ziraat Fakültesi Dergisi, 2007, 20(2),171-182.

Aktaş T. 2018. Vermikompostun farklı tekstüre sahip topraklarda bitki gelişimine ve toprakların fiziksel kimyasal özelliklerine etkisi. MSc Thesis., Institue of Natural and Applied Sciences, Tekirdağ Namık Kemal University, Tekirdağ, Turkey.
Alvarez JM, Pasian C, Lal R, López R, Fernández M. 2017.Vermicompost and Biochar as Substitutes of Growing Media in Ornamental-Plant Production. Journal of Applied Horticulture, 19(3): 205-214. doi: 10.37855/jah.2017.v19i03.37

Anonymous, 2020. Organik Gübreler ve Önemi. T.C. Samsun Valiliği İl Tarım Müdürlüğü. Available from: https://samsun.tarimorman.gov.tr/Belgeler/Yayinlar/Kitaplar imiz/organik_gubreler_ve_onemi.pdf [Accessed 26 January 2021]

Arancon NQ, Owens JD, Converse C. 2019. The effects of vermicompost tea on the growth and yield of lettuce and tomato in a non-circulating hydroponics system. Journal of Plant Nutrition. DOI: https://doi.org/10.1080/01904167. 2019.1655049.

Arancon, NQ. 2012. Seed Germination and Seedling Growth of Tomato and Lettuce as Affected by Vermicompost Water Extracts (Teas). HortScience. DOI: https://doi.org/ 10.21273/HORTSCI.47.12.1722

Atak M. 2004. Farklı Triticale Hatlarını Morfolojik ve DNA Markörleriyle Genetik Karakterizasyonu. PhD Dissertation. Graduate School of Natural and Applied Sciences ,Ankara University, Ankara, Turkey.

Barlas NT, Cönkeroğlu B, Ünal G, Bellitürk K. 2018. The Effect of Different Vermicompost Doses on Wheat (Triticum vulgaris L.) Nutrition. Journal of Tekirdağ Agricultural Faculty, 2018: 15(02), 1-4. ISSN 1302-7050 eISSN 2146-5894.

McGoverin CM, Snyders F, Muller N, Botes W, Fox G, Manley M. 2011. A review of triticale uses and the effect of growth environment on grain quality. Journal of the Science of Food and Agriculture. DOI: https://doi.org/10.1002/jsfa.4338

Cheraghi Y, Mohyedi FA, Kalhor M. 2016. Effects of Organic and Chemical Fertilizers on Yield Components of Common Wheat (Triticum aestivum L.). IIOAB Journal. Appl. Res. in Biol. Sci., Vol. 7, 882-86. ISSN: 0976-3104

Çiftçi İ, Yenice E, Eleroğlu E. 2003. Use of Triticale Alone and in Combination with Wheat or Maize: Effect of Diet Type and Enzyme Supplementation on Hen Performance, Egg Quality, Organ Weights, Intestinal Viscosity and Digestive System Characteristics. Animal Feed Science and Technology, 105; 149- 161. doi: 10.1016/S0377-8401(03)00010-5

Coşkan A, Yılmaz K. 2015. Effects of vermicompost extract tea on tomato seedling production. In: Dr. Evgeny Shein (Editor). The Proceedings of the International Congress on "Soil Science in International Year of Soils". Russia, 19-23 October, 2015, Sochi, pp. 80-83.

Coşkan A, Şenyiğit U. 2018. Effects of Different Irrigation Water Levels and Vermicompost Doses on Micro Nutrient Uptake of Lettuce Plant. Süleyman Demirel Üniversitesi Ziraat Fakültesi Dergisi, 1. Uluslararası Tarımsal Yapılar ve Sulama Kongresi Özel Sayıs1: 348-356, 2018. e-ISSN : 2619-9149

Demir İ, Aydın N, Korkut KZ. 1981. İleri tritikale hatlarının bazı agronomik özellikleri üzerine araştırmalar. Ege Üniv. Zir. Fak. Derg., 18:227-238. ISSN 1018-8851. eISSN 2548-1207

Ekinci M, A. Dursun, E. Yıldırım, F. Parlakova. 2014. Effects of nanotechnology liquid fertilizers on the plant growth and yield of cucumber (Cucumis sativus L.). Acta Scientiarum Polonorum, Hortorum Cultus. 13. 135-141.

FAO, 2019. Food and Agriculture Organization of the United Nations. FAOSTAT. Available from: http://www.fao.org/ faostat/en/\#data/QC [Accessed 15 January 2021]

Fernandez-Figares I, Marinetto J, Royo C, Ramos JM, Garcia del Moral LF. 2000. Amino-Acid Composition and Protein and Carbohydrate Accumulation in The Grain of Triticale Grown Under Terminal Water Stress Simulated by a Senescing Agent. Journal of Cereal Science. DOI: https://doi.org/ 10.1006/jcrs.2000.0329

Genç İ, Ülger AC, Yağbasanlar T, Kırtok Y, Topal N. 1988. Çukurova koşullarında tritikale, buğday ve arpanın verim ve verim öğeleri üzerinde bir araştırma. Çukurova Üniv. Zir.Fak. Derg., 3: 1-13. ISSN: 2636-7874 / 2630-6034 
Gowda C, Patil NKB, Patil BN, Awaknavar JS, Ninganur BT, Hunje R. 2008. Effect of organic manures on growth, seed yield and quality of wheat. Karnataka J. Agric. Sci., 21(3): 366-368. University of Agricultural Sciences, Dharwad - 580 005 , India.

Günhan T. 2020. Determination of The Effects of Reduced Nitrogen Fertilizer Applications and Vermicompost Combinations on Yield Components of Pehlivan Bread Wheat Variety (Triticum aestivum L.). MSc Thesis. Graduate School of Natural and Applied Sciences, Bursa Uludağ University, Bursa, Turkey.

Kacar B, Katkat V. 2018. Gübreler ve Gübreleme Tekniği, 6. Basım. Nobel Akademik Yayınc1lık. ISBN 97-605-5426-200. e-ISBN 978-625-402-847-2.

Karaşahin M. 2014. Nitrogen Uptake Efficiency in Plant Production and Negative Effects of Reactive Nitrogen on Environment. APJES II-III. DOI: https://doi.org/ 10.5505/apjes.2014.38247

Levinsh G. 2011. Vermicompost treatment differentially affects seed germination, seedling growth and physiological status of vegetable crop species. Plant Growth Regulation, 65:169181. doi: 10.12691/wjar-3-4-2

Mamnabi S, Nasrollahzadeh S, Golezani KG, Raei Y. 2020. Improving yield-related physiological characteristics of spring rapeseed by integrated fertilizer management under water deficit conditions. Saudi Journal of Biological Sciences. DOI: https://doi.org/10.1016/j.sjbs.2020.01.008

Martin CA, Maurer O R. 1974. Introduction, Adaptation and Selection of Tritikale at Apodaca, Nueve Leon. Field Crops Abst. 17: 6102.

Morales-Corts MR, Sanchez RP, Sanchez MAG. 2018. Efficiency of garden waste compost teas on tomato growth and its suppressiveness against soilborne pathogens. DOI: https://doi.org/10.1590/1678-992x-2016-0439.

Navarro-Contreras AL, Chaires-González CF, Rosas-Burgos EC, Borboa-Flores J, Wong-Corral FJ, Cortez-Rocha MO, CincoMoroyoqui FJ. 2014. Comparison of protein and starch content of substituted and complete triticales (X Triticosecale Wittmack): Contribution to functional properties. International Journal of Food Properties, 421-432. https://doi.org/10.1080/10942912.2011.642440

Okur N, Kayıkçığlu HH, Tunç G, Tüzel Y. 2007. The effect of some organic amendments using in organic agriculture on microbial activity in soil. Journal of Agriculture Faculty of Ege University, 44 (2):65-80. ISSN 1018-8851. eISSN 25481207.
Özen HÇ, Onay A. 2007. Bitki Fizyolojisi. Nobel Akademik Yayıncılık. ISBN 978-605-133-480-6

Quiroz MC, Lopez-Espinosa ST, Sanchez-Chavez E, GarciaBañuelos ML, De la Cruz-Lazaro E, Reyes-Carrillo JL. 2014. Effect of vermicompost tea on yield and nitrate reductase enzyme activity in saladette tomato. DOI: http://dx.doi.org/10.4067/S0718-95162014005000018.

Rostami M, Olia M, Arabi M. 2014. Evaluation of the effects of earthworm Eisenia fetida-based products on the pathogenicity of root-knot nematode (Meloidogyne javanica) infecting cucumber. International Journal of Recycling of Organic Waste in Agriculture, DOI: https://doi.org/10.1007/s40093014-0058-y

Sönmez F, Çı̆̆ F, 2019. Determination of Effects of Increasing Dose Biochar and Vermicompost Applications on Nutrient Content in Wheat and Soil. KSU J. Agric Nat 22(4): 526-536. doi:10.18016/ksutarimdoga.vi.516812

Sönmez İ, Kaplan M, Sönmez S. 2008. Effect of Chemical Fertilizers on Environmental Pollution and Its Prevention Methods. Batı Akdeniz Tarımsal Araştırma Enstitüsü Derim Dergisi, 2008, 25(2): 24-34 ISSN 1300-3496.

Süzer, S., 2020. Organik (Ekolojik) Tarım. Available from: https://arastirma.tarimorman.gov.tr/ttae/Sayfalar/Detay.aspx ?SayfaId=66. [Accessed 31 December 2020]

Tankuş Ö. 2019. The Effect of Different Doses of Vermicompost Applications on The Growth of Maize (Zea mays L.). MSc Thesis, Graduate School of Applied and Natural Sciences, Harran University, Şanlıurfa, Turkey.

Teke Ş, Coşkan A, Aktaş H, 2019. The Effects of Vermicompost on Yield and Quality Parameters in Tomato. Turkish Journal of Science and Engineering. 1(1): 23-27, 2019. ISSN (online) 2147-9690

Tosun M, Akgün İ, Sağsöz S, Taşpınar M. 2000. Yazlık ekilen tritikale genotiplerinde verim ve verim ögelerinin belirlenmesi. Atatürk Üniv. Zir. Fak. Derg., 31 (1) 1-10. ISSN: 1300-9036. E-ISSN: 2651-5016

Uçar Ö, Soysal S, Erman M. 2020. The Effects of Solid Vermicompost Applications on the Yield and Yield Components of Chickpea (Cicer arietinum L.) in the Ecological Conditions of Siirt. T. Journal of Nature and Science. Vol. 9, Issue 2, Page 91-95, 2020. doi: $10.46810 /$ tdfd. 806329

Yağbasanlar T, Ülger AC, Genç İ. 1989. Çukurova koşullarında bazı tritikale (x Triticosecale Wittmack) hatlarının uyum yetenekleri üzerinde bir araştırma. Çukurova Üni. Zir. Fak. Der., 4:83-90. ISSN: 2636-7874 / 2630-6034 